\title{
Pengukuran Konstanta Dielektrik Udara pada Perangkat Kapasitor Plat-Sejajar Berbasis Mikrokontroler Arduino Uno
}

\author{
Andrian Wijayono ${ }^{1^{*}}$ dan Valentinus Galih Vidia Putra ${ }^{2}$ \\ 1,2 Jurusan Teknik Tekstil, Politeknik STTT Bandung \\ Jalan Jakarta No.31 Bandung, Bandung, Jawa Barat, Indonesia 40272 \\ *E-mail: andrianwijayono@windowslive.com
}

\begin{abstract}
Abstrak
Penelitian ini bertujuan untuk merancang sebuah prototipe alat pengukur konstanta dielektrik udara dan dapat untuk mengukur nilai kapasitansi menggunakan perangkat mikrokontroler Arduino. Pengukuran konstanta dielektrik udara dilakukan dengan melalui prinsip pengukuran kapasitansi dari perangkat kapasitor berkonfigurasi plat-sejajar dengan bahan dielektrik udara. Pengukuran kapasitansi dilakukan dengan prinsip pengisian dan pengosongan kapasitor menggunakan perangkat mikrokontroler Arduino Uno. Proses pengisian dan pengosongan dilakukan dengan menggunakan susunan seri rangkaian resistor-kapasitor (RC) dengan tegangan sumber sebesar 5 Volt dari perangkat mikrokontroller. Pada eksperimen ini telah digunakan sebuah plat sejajar dengan ukuran $29 \times 30 \mathrm{~cm}$ sebagai elektroda kapasitor, serta sebuah perangkat resistor dengan ukuran 125 megaOhm. Hasil penelitian menunjukan bahwa perilaku pengisian dan pengosongan perangkat kapasitor plat-sejajar memiliki nilai $\mathrm{R}$ square $>0,9$, yang menunjukan korelasi cukup baik antara hasil prediksi dan eksperimen pada pengukuran kapasitansi. Hasil penelitian memperlihatkan bahwa prototype alat pengukur konstanta dielektrik dapat dirancang dengan baik dengan memperlihatkan nilai kapasitansi alat pada keadaan pengisian dan pengosong serta hasilpengukuran menunjukan nilai konstanta dielektrik udara telah diukur dengan nilai sebesar $0,991-1.0346$.
\end{abstract}

Kata kunci: kapasitor, konstanta dielektrik, pengisian, pengosongan,

\begin{abstract}
This study aims to design a prototype of an air dielectric constant measuring device and be able to measure the capacitance value using an Arduino microcontroller device. The measurement of the air dielectric constant is carried out by means of the principle of measuring the capacitance of a capacitor device with a plate-parallel configuration with the air dielectric material. Capacitance measurements are carried out with the principle of charging and emptying capacitors using an Arduino Uno microcontroller device. The charging and discharging process is carried out using a series of resistor-capacitor $(R C)$ series with a source voltage of 5 volts from the microcontroller device. This experiment has used a parallel plate with a size of $29 \times 30 \mathrm{~cm}$ as an electrode capacitor, and a resistor device with a size of 125 megaOhm. The results showed that the behavior of charging and discharging parallel plate capacitor devices has an $R$ square value of $>0.9$, which shows a fairly good correlation between the predicted and experimental results on capacitance measurements. The results showed that the prototype of a dielectric constant measuring device can be well designed by showing the capacitance value of the device at the state of filling and emptying and the measurement results show the value of the air dielectric constant has been measured with a value of $0.991-1.0346$.
\end{abstract}

Keywords: capacitor, dielectric constant, charging, discharging

\section{PENDAHULUAN}

Penerapan fisika dalam berbagai bidang elektronik telah secara luas dilakukan oleh berbagai peneliti. Pengamatan mengenai nilai konstanta dielektrik bahan untuk berbagai kegunaan telah banyak dilakukan oleh beberapa peneliti (Argin \& Karady, 2008; Bandyopadhyay dkk, 1980; Karady dkk, 2004; Karady dkk, 2003; Knott, 1993). Beberapa peneliti telah mengembangkan alat yang dapat mengukur konstanta dielektrik udara namun tidak dapat memperlihatkan pengukuran real time pada proses pengisian dan pengosongan muatan (Hidayat dkk, 2013; Prihatnolo dkk, 
2011; Rosita \& Widodo, 2014). Prihatnolo, dkk (2011) menjelaskan bahwa besarnya konstanta dielektrik udara berhubungan dengan sifat isolasi udara terhadap arus listrik. Sifat isolasi adalah hal yang paling penting dan tidak dapat dipisahkan pada peralatan tegangan tinggi (Prihatnolo dkk, 2011). Hidayat, dkk (2013) dan Rosita, dkk (2014) telah mengembangkan alat yang dapat mengukur konstanta dielektrik material dengan menggunakan sistem LCR meter. Nilai konstanta dielektrik udara yang diperoleh oleh Hidayat, dkk (2013) dan Rosita \& Widodo (2014) berperan sebagai nilai acuan pembanding terhadap nilai konstanta dielektrik secara literature, kelemahan dari alat ini adalah tidak dapat diperlihatkan data real time proses pengisian kapasitor dan pengosongan kapasitor.Pada penelitian Rizza, dkk (2018), Pereira, dkk (2016) dan Cahyono, dkk (2017), pengukuran dielektrik dilakukan dengan menggunakan perangkat kapasitor dengan konfigurasi plat sejajar (parallel-plate). Pengukuran konstanta dielektrik material berkaitan dengan pengukuran kapasitansi (Juansah \& Irmansyah, 2007; Arum dkk, 2015). Menurut Putra \& Purnomosari (2016), pada kapasitor dengan konfigurasi plat sejajar akan berlaku rumusan kapasitansi seperti pada persamaan (1).

$$
C=\varepsilon_{0} \varepsilon_{r} \frac{A}{d}
$$

Sesuai dengan persamaan (1), $C$ adalah besar kapasitansi kapasitor, $\varepsilon_{0}$ adalah besarnya permitivitas vakum, $\varepsilon_{r}$ adalah besarnya permitivitas relatif, $d$ adalah jarak antar kedua plat sejajar kapasitor dan $A$ adalah luasan daerah plat sejajar kapasitor. Pada dasarnya kapasitor terdiri dari dua pelat konduktor yang dipasangberdekatan satu sama lain tapi tidak sampaibersentuhan (Allagui, dkk 2018). Kapasitor dapat menyimpantenaga listrik dan dapat menyalurkannyakembali (Halliday, Resnick, Walker, 1997).. Peristiwa pengisian dan pengosonganmuatan kapasitor memegang peranan penting dalam elektronika (Halliday, Resnick, Walker, 1997). Sistem kapasitansi telah digunakan oleh beberapa peneliti untuk berbagai aplikasi, yaitu untuk aplikasi activity monitoring (Arshad, dkk 2016), pengukuran kapasitansi graphene (Xia dkk, 2009), sensor pada bidang health monitoring (Mukhopadhyay, 2015; Coyle, dkk 2010; Min, dkk 2014; Hoffmann, dkk 2011; Cheng, dkk 2013; Lee, dkk 2015; Salvo, dkk 2010), serta pengukuran sensor humidity (Kondalkar, dkk 2019).Menurut Putra \& Purnomosari (2016), rumusan hubungan tegangan kapasitor $V(t)$ terhadap waktu $t$ pada proses pengisian (charging) akan sesuai dengan persamaan (2), sedangkan hubungan tegangan kapasitor $V(t)$ terhadap waktu $t$ pada proses pengosongan (discharging) akan sesuai dengan persamaan (3). Nilai tegangan kapasitor terhadap waktu akan meningkat secara eksponensial pada proses pengisian hingga mencapai keadaan steady state, sedangkan nilai tegangan kapasitor terhadap waktu akan meluruh secara eksponensial pada proses pengosongan hingga tegangan bernilai nol(Dean, dkk 2013; Tang, dkk 2019; Putra \& Purnomosari, 2016). Gambar 1 menunjukan grafik hubungan antara tegangan kapasitor $V(t)$ terhadap waktu $t$ pada proses pengisian (charging) dan pengosongan (discharging).

$$
\begin{gathered}
V=\frac{Q}{C}=\varepsilon\left(1-e^{-\frac{t}{R C}}\right) \\
V=\varepsilon e^{-\frac{t}{R C}}
\end{gathered}
$$

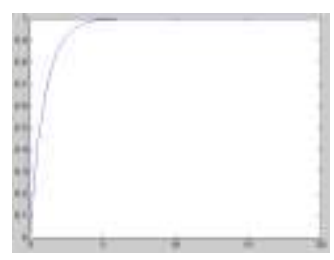

(a)

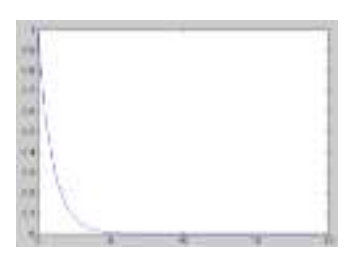

(b)
Gambar 1. Hubungan antara tegangan kapasitor $V(t)$ terhadap waktu $t$ pada;

(a) proses pengisian (charging) dan

(b) proses pengosongan (discharging)

(Putra \& Purnomosari, 2016)

Putra, dkk (2019) telah berhasil merancang suatu metode untuk mengukur kapasitansi dengan cukup baik (dengan nilai $\mathrm{R}^{2}$ lebih besar dari 0,9) menggunakan perangkat mikrokontroller Arduino Uno. Pengukuran kapasitor dapat dilakukan dengan metode pengisian (charging) dan pengosongan (discharging) sebuah perangkat kapasitor yang tersusun secara seri dengan 
sebuah resistor (rangkaian $\mathrm{R}-\mathrm{C}$ ) dan terhubung dengan perangkat Mikrokontroller Arduino Uno. Pada penelitian ini, perangkat mikrokontroller mengambil peranan penting sebagai perangkat akusisi data. Penelitianmengenai akuisisi data kapasitor telah menjadihal yang penting dan telah dilakukan oleh parapeneliti (Arshad, dkk, 2016; Laflamme, dkk 2013; Laflamme,dkk 2015).Menurut Putra \& Purnomosari (2016), pengukuran konstanta dielektrik udara didasarkan pada rumusan kapasitor plat sejajar pada persamaan (4) dengan nilai kapasitansi $C$ hasil pengukuran, serta luasan elektroda $A$ dan nilai jarak antar elektroda $d y a n g$ telah diketahui. Pengukuran dielektrik udara telah dilakukan pada konfigurasi elektroda kapasitor plat-sejajar (parallel-plate) berbasis Arduino yang merekam dan menampilkan data hasil pengukuran pada layar serial monitor. Pada penelitian ini telah diamati pengaruh dari jarak elektroda plat sejajar terhadap nilai kapasitansi dari perangkat kapasitor yang dirancang.

$$
\varepsilon_{r}=\frac{C d}{A \varepsilon_{0}}
$$

Sesuai dengan rumusan pada persamaan (1), (2) dan (3), maka rumusan hubungan tegangan kapasitor terhadap waktu untuk kapasitor plat sejajar pada proses charging dapat dituliskan sesuai dengan persamaan (5).

$$
V=\varepsilon\left(1-e^{-\frac{t d}{R \varepsilon_{0} \varepsilon_{r} A}}\right)=\varepsilon\left(1-e^{-t b}\right)
$$

Rumusan hubungan tegangan kapasitor terhadap waktu untuk kapasitor plat sejajar pada proses charging dapat dituliskan sesuai dengan persamaan (6).

$$
V=\varepsilon e^{-\frac{t d}{R \varepsilon_{0} \varepsilon_{r} A}}=\varepsilon e^{-t b}
$$

\section{METODE EKSPERIMEN}

Perancangan sistem pengukuran diawali dengan perancangan dan fabrikasi elektroda sensor yang ukuran bahan disesuaikan dengan persamaan 4, 5 dan 6 . Elektroda sensor yang digunakan pada penelitian ini adalah elektroda kapasitor plat sejajar.Pada tahap ini dilakukan perancangan desain elektroda kapasitor plat sejajar dengan spesifikasi pada Tabel 1. Agar nilai $\mathrm{C}$ dapat diamati dan konstanta dielektrik dapat ditentukan dari persamaan 4, maka dirancang agar grafik pengisian dan pengosongan memiliki durasi waktu yang cukup lama dengan membuat besar luasan lempengan menjadi cukup besar dibandingkan ketebalan jarak antar lempengan $(30 \mathrm{~cm} \times 29 \mathrm{~cm})$, namun jarak antara dua plat cukup kecil $(0.01 \mathrm{~mm})$. Rancangan disesuaikan dengan ketersediaan bahan dan fungsinya agar pembuatan prototipe dapat dirancang dengan biaya yang minimal dan hasil luaran yang baik. Rancangan elektroda plat sejajar dapat dilihat pada Gambar 2(a). Jarak antar plat elektroda diatur menggunakan lempeng isolator dengan ketebalan tertentu $(0.01 \mathrm{~mm})$ sesuai ilustrasi pada Gambar 2(b). Plat elektroda yang digunakan terbuat dari bahan lempengan aluminium dengan ketebalan $\quad 0,01 \mathrm{~mm}$.

Tabel 1. Desain spesifikasi elektroda sensor

\begin{tabular}{cc}
\hline Parameter & Ukuran \\
\hline Panjang elektroda $(\mathrm{p})$ & $30 \mathrm{~cm}$ \\
\hline Lebar elektroda $(\mathrm{I})$ & $29 \mathrm{~cm}$ \\
\hline Tebal elektroda $(\mathrm{t})$ & $0,01 \mathrm{~mm}$ \\
\hline Jarak antar elektroda $(\mathrm{d})$ & $1 \mathrm{~mm} ; 2 \mathrm{~mm} ; 3 \mathrm{~mm}$ \\
\hline
\end{tabular}
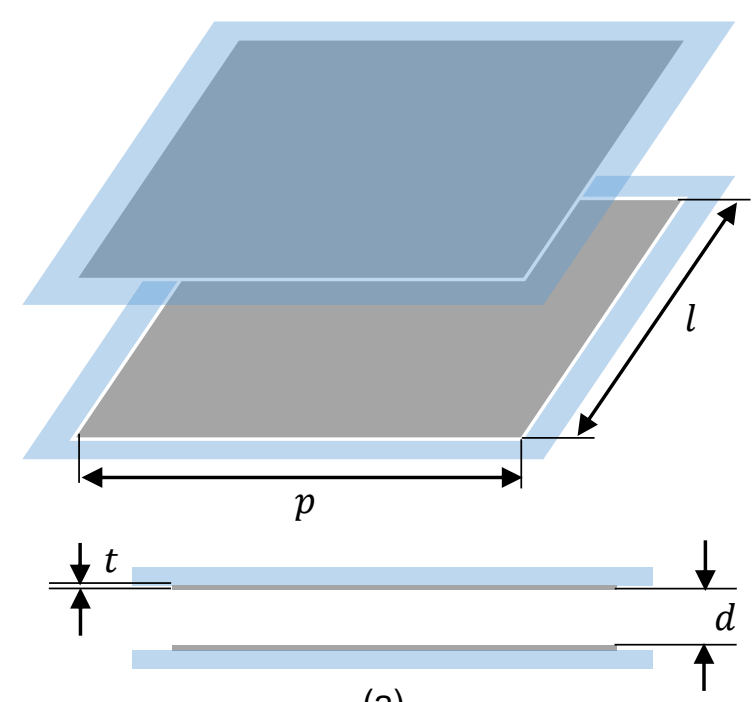

(a)

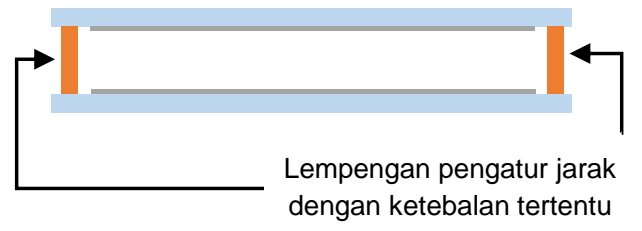

(b)

Gambar 2. (a) Rancangan elektroda plat 
sejajar; (b) pengaturan jarak antar plat elektroda

Desain rancangan konfigurasi plat elektroda yang digunakan pada penelitian ini sesuai dengan susunan pada Gambar 2. Gambar 3 menunjukan hasil rancangan elektroda sesuai dengan susunan pada Gambar 2.

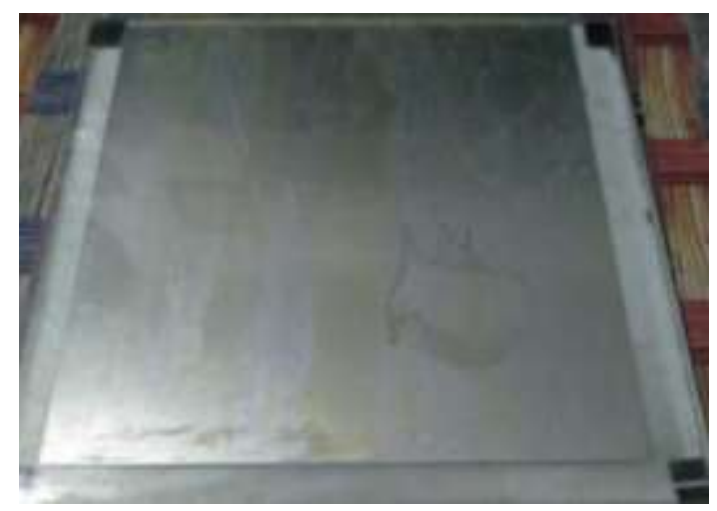

(a)

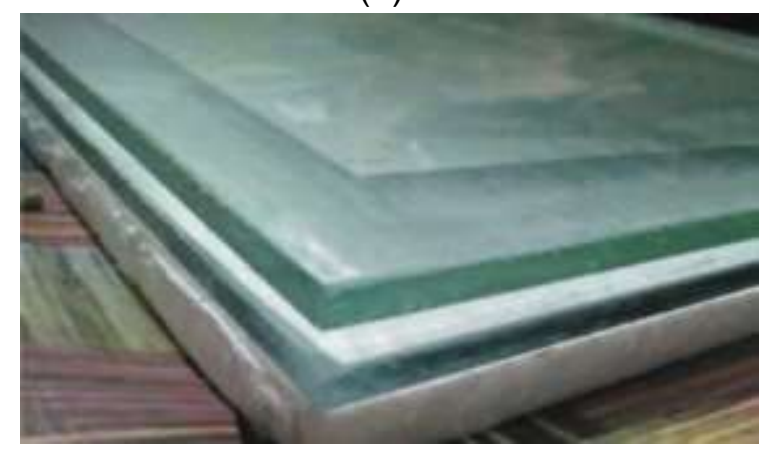

(b)

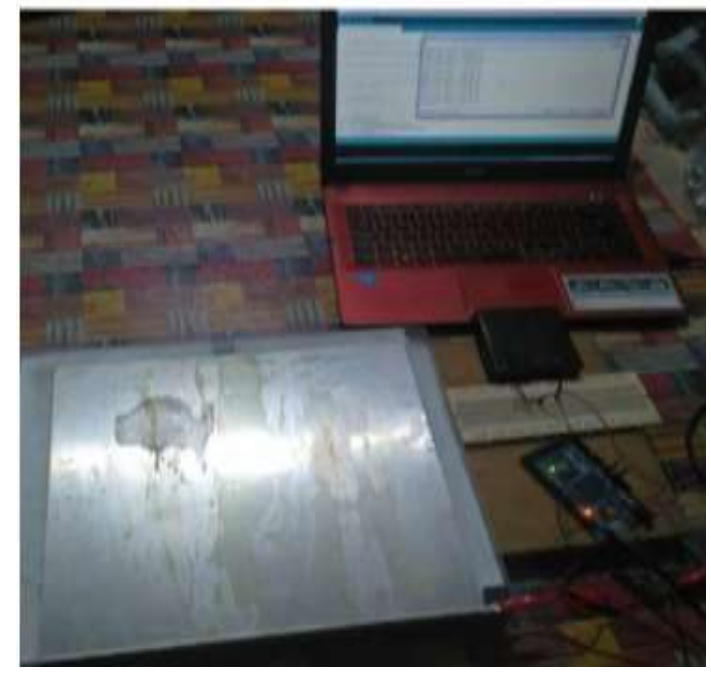

(c)

Gambar 3. Elektroda plat sejajar hasil fabrikasi

(a) tampak atas, (b) tampak samping, (c) pengukuran konstanta dielektrik udara

Tahapan kedua pada penelitian ini adalah perancangan sistem pengukuran kapasitansi berbasis mikrokontroler Arduino Uno. Rangkaian sistem pengukuran kapasitansi pada proses pengisian (charging) kapasitor dapat dilihat sesuai dengan Gambar 4. Besar tegangan sumber yang digunakan adalah sebesar 5 Volt. Gambar 4 menunjukan rangkaian kapasitor dan sensor yang tersusun dalam rangkaian seri, yang terhubung pada Pin A0, Pin 5V dan pin GND. Gambar 5 menunjukan rangkaian sistem pengukuran kapasitansi pada proses pengosongan (discharging) perangkat kapasitor.

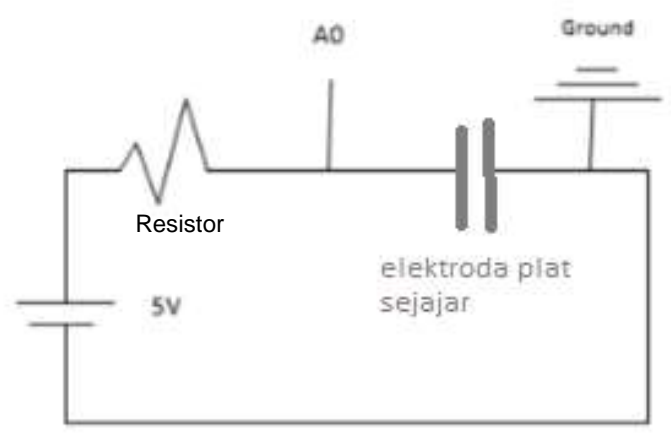

Gambar 4. Rangkaian sistem pengukuran kapasitansi pada proses pengisian kapasitor (charging)

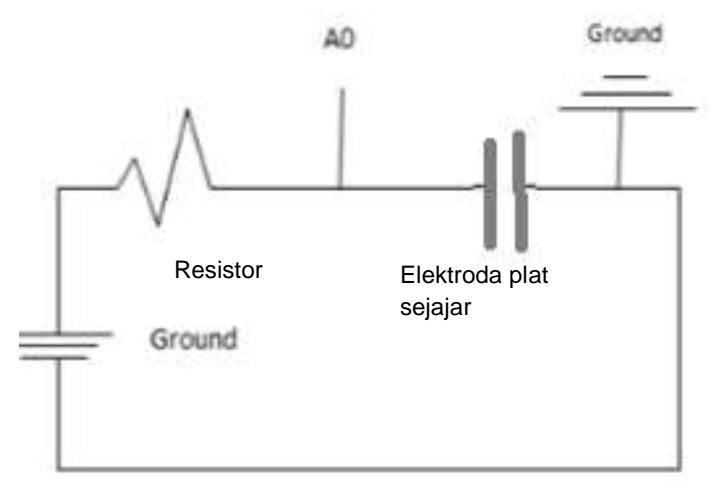

Gambar 5. Rangkaian sistem pengukuran kapasitansi pada proses pengosongan kapasitor (discharging)

Prosedur metode pengukuran kapasitansi dapat dijelaskan sebagai berikut:

1. Membuat program Arduino pada komputer

2. Resistor dan kapasitor dirangkai sesuai dengan skema pada Gambar 4.

3. Perangkat sistem pengukuran kapasitansi dihubungkan ke komputer.

4. Program dimasukan pada Arduino.

5. Perangkat elektroda diisi hingga 
mencapai tegangan maksimum $5 \mathrm{~V}$ atau sampai nilainya konstan.

6. Perangkat elektroda dikosongkan dari $5 \mathrm{~V}$ hingga OV atau hingga nilainya konstan.

7. Perhitungan konstanta dielektrik dilakukan pada Microsoft Excel untuk membandingkan hasil eksperimen dan hasil teori.

8. Tahapan 1-7 diulangi untuk jarak elektroda masing-masing $1 \mathrm{~mm}, 2 \mathrm{~mm}$ dan $3 \mathrm{~mm}$.

\section{HASIL DAN PEMBAHASAN}

Pada penelitian ini telah dilakukan pengukuran nilai konstanta dielektrik udara dengan cara mengukur nilai kapasitansi elektroda plat sejajar. Nilai kapasitansi diperoleh dengan metode pengisian (charging) dan pengosongan (discharging)elektroda, yang kemudian direkam oleh Arduino dan diolah menggunakan metode fitting data terhadap persamaan (2) dan (3). Nilai konstanta dielektrik udara diperoleh sesuai dengan rumusan kapasitor plat sejajar pada persamaan (5) dan (6).

\section{HASIL}

Pengukuran konstanta dielektrik udara pada kondisi pengisian (charging)

Pengujian kali ini yaitu pengisian (charging) pada elektroda plat sejajar (dengan jarak antar elektroda $1 \mathrm{~mm}$ ) dengan dielektrik udarayang dilakukanmenggunakan tegangan sumber $5 \mathrm{~V}$. Pengisian (charging) dilakukan sesuai dengan skema rangkaian pada Gambar 4. Prosesini disebutsebagai proses pengisian secara eksperimen sehingga menghasilkan tegangan eksperimen pada setiap 20 milisecond dari tegangan awal 0 volt hingga 5 volt yang kemudian akan dibandingkan dengan hasil prediksi teori. Tabel 2 menunjukan data tegangan eksperimen pada proses pengisian elektroda kapasitor plat sejajar berdielektrik udara.(jarak antar elektroda $1 \mathrm{~mm}$; tegangan sumber 5 Volt; resistor 125 megaOhm).

Tabel 2. Data nilai perubahan tegangan tiap waktu pada pengisian kapasitor elektroda plat sejajar berdielektrik udara (dengan jarak antar elektroda $1 \mathrm{~mm}$; tegangan sumber 5 Volt; resistor 125 megaOhm)

\begin{tabular}{|c|c|c|c|c|c|}
\hline $\begin{array}{c}V \\
\text { eksp }\end{array}$ & $T$ & B & $\begin{array}{c}V \\
\text { teori }\end{array}$ & $\left(\mathrm{V}_{\mathrm{te}}-\mathrm{V}_{\mathrm{eksp}}\right)^{2}$ & $\left(V_{\text {avg }}-V_{\text {eksp }}\right)^{2}$ \\
\hline 0 & 0 & 10.30 & 0.00 & 0.0000 & 14.2797 \\
\hline 0.22 & 0.02 & 10.30 & 0.93 & 0.5056 & 12.6654 \\
\hline 1.12 & 0.04 & 10.30 & 1.69 & 0.3235 & 7.0695 \\
\hline 1.81 & 0.06 & 10.30 & 2.31 & 0.2454 & 3.8764 \\
\hline 2.36 & 0.08 & 10.30 & 2.81 & 0.1999 & 2.0131 \\
\hline 2.8 & 0.1 & 10.30 & 3.22 & 0.1726 & 0.9581 \\
\hline 3.15 & 0.12 & 10.30 & 3.55 & 0.1582 & 0.3954 \\
\hline 3.45 & 0.14 & 10.30 & 3.82 & 0.1356 & 0.1081 \\
\hline 3.72 & 0.16 & 10.30 & 4.04 & 0.1013 & 0.0035 \\
\hline 3.95 & 0.18 & 10.30 & 4.22 & 0.0715 & 0.0293 \\
\hline 4.15 & 0.2 & 10.30 & 4.36 & 0.0454 & 0.1378 \\
\hline 4.32 & 0.22 & 10.30 & 4.48 & 0.0261 & 0.2928 \\
\hline 4.46 & 0.24 & 10.30 & 4.58 & 0.0140 & 0.4640 \\
\hline 4.57 & 0.26 & 10.30 & 4.66 & 0.0075 & 0.6259 \\
\hline 4.66 & 0.28 & 10.30 & 4.72 & 0.0037 & 0.7764 \\
\hline 4.73 & 0.3 & 10.30 & 4.77 & 0.0018 & 0.9047 \\
\hline 4.78 & 0.32 & 10.30 & 4.82 & 0.0012 & 1.0023 \\
\hline 4.81 & 0.34 & 10.30 & 4.85 & 0.0016 & 1.0633 \\
\hline 4.83 & 0.36 & 10.30 & 4.88 & 0.0023 & 1.1049 \\
\hline 4.86 & 0.38 & 10.30 & 4.90 & 0.0016 & 1.1689 \\
\hline 4.88 & 0.4 & 10.30 & 4.92 & 0.0015 & 1.2125 \\
\hline 4.91 & 0.42 & 10.30 & 4.93 & 0.0006 & 1.2795 \\
\hline 4.92 & 0.44 & 10.30 & 4.95 & 0.0007 & 1.3022 \\
\hline 4.94 & 0.46 & 10.30 & 4.96 & 0.0003 & 1.3483 \\
\hline 4.95 & 0.48 & 10.30 & 4.96 & 0.0002 & 1.3716 \\
\hline 4.9 & 0.5 & 10.30 & 4.97 & 0.0050 & 1.2570 \\
\hline $\begin{array}{c}\bar{x} \\
3.778\end{array}$ & & & & $\begin{array}{l}\text { Jumlah } \\
2,0272\end{array}$ & $\begin{array}{l}\text { Jumlah } \\
56,7107\end{array}$ \\
\hline
\end{tabular}

Untuk menentukan nilai tegangan secara teori maka dapat menggunakan persamaan (7).

$$
b=\frac{d}{R \varepsilon_{0} \varepsilon_{r} A}
$$

Persamaan tersebut berasal dari persamaan nilai perubahan tegangan terhadap waktu untuk proses charging kapasitor elektroda plat sejajar sesuai persamaan (5). Nilai $b$ merupakan hasil fitting dataantara data hasil eksperimen terhadap persamaan (5). 
Pada pengujian ini diketahui nilai resistansi $R$ sebesar 125 megaOhm, jarak antar elektroda $d$ sebesar 0,001 meter, luasan elektroda $A$ sebesar 0,087 meter $^{2}$, dan nilai $\varepsilon_{0}$ sebesar $8,85 \times 10^{-12} \mathrm{~F} / \mathrm{m}$, serta nilai $b$ yang diperoleh dari fitting data sebesar 10,3029, maka nilai $\varepsilon_{r}$ dapat ditentukan sebagai berikut(persamaan (9)).

$$
\varepsilon_{r}=\frac{d}{R \varepsilon_{0} b A}
$$

$$
\varepsilon_{r}=\frac{(0,001)}{\left(125 \times 10^{6}\right)\left(8,85 \times 10^{-12}\right)(10,3029)(0,087)}
$$

Untuk melihat keakuratan penentuan nilai konstanta dielektrik udara berdasarkan data nilai tegangan secara eksperimen, data diplotkan pada grafik yang ditunjukan pada Gambar 6.

Dari kurvapada Gambar 6 dapat dilihat perbedaanantara tegangan secara eksperimen dan teori sangat sedikit untuk melihat nilai keakuratannya, maka dicari $\mathrm{R}^{2}$ dari kurva tersebut dengan menggunakan teorema fitting. Persamaan (9) merupakan hasil perhitungan $\mathrm{R}^{2}$ untuk melihat kesesuaian antara nilai teori dan nilai eksperimen.

$$
\begin{gathered}
R^{2}=1-\frac{\sum\left(\mathrm{V}_{\text {te }}-\mathrm{V}_{\text {eksp }}\right)^{2}}{\sum\left(\mathrm{V}_{\text {avg }}-\mathrm{V}_{\text {eksp }}\right)^{2}}=1-\frac{2,0272}{56,7107} \\
=0.964253619
\end{gathered}
$$

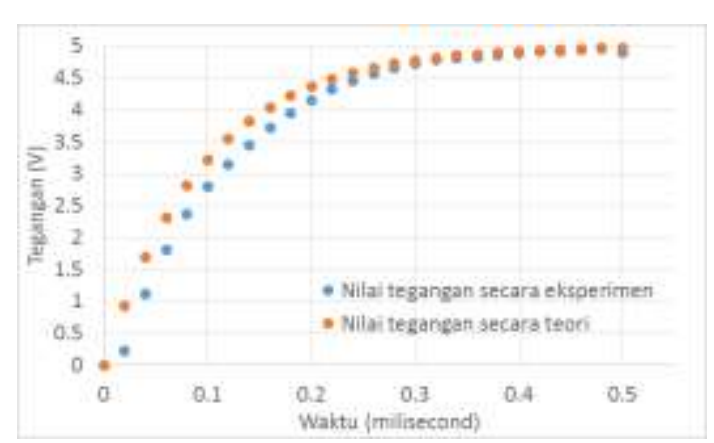

Gambar 6. Kurva perubahan tegangan $V_{c}(t)$ (kapasitor elektroda plat sejajar berdielektrik udara dengan jarak antar elektroda $1 \mathrm{~mm}$; tegangan sumber 5 Volt; resistor 125 megaOhm)

Dapat dilihat dari $\mathrm{R}^{2}$ perhitungan sebelumnya bahwa tegangansecara eksperimen sesuai dengan tegangan secara teori, hal ini menunjukanmetode ini dapat digunakan untuk menentukan nilai konstanta dielektrik udara. Berdasarkan nilai $\mathrm{R}^{2}$ diatas dapat dikatakan bahwa antara eksperimendan teori hasilnya hampirmendekati nilai yangsama. Sesuai dengan persamaan (1), nilai kapasitansi dari kapasitor elektroda plat sejajar pada eksperimen tersebut adalah sebesar 7,765 × 10-10 Farad.

Semakin besar nilai jarak antar elektroda maka akan semakin kecil kapasitansi. Pada penelitian ini telah diamati pengaruh jarak antar elektroda terhadap hasil pengukuran nilai kapasitansi perangkat kapasitor plat sejajar dan konstanta dielektrik udara. Dalam pengujian ini dapat dibandingkan antara kapasitor plat sejajar dengan jarak antar elektroda masing-masing 1 $\mathrm{mm}, 2 \mathrm{~mm}$ dan $3 \mathrm{~mm}$. Pada Tabel 3 di bawah ini adalah hasil akuisisi data nilai tegangan secara eksperimen dan teori untuk kapasitor elektroda plat sejajar berdielektrik udara pada proses pengisian dengan jarak antar elektroda $2 \mathrm{~mm}$, tegangan sumber 5 Volt, dan hambatansebesar 125 megaOhm.

Tabel 3. Data nilai perubahan tegangan tiap waktu pada pengisian kapasitor elektroda plat sejajar berdielektrik udara (dengan jarak antar elektroda $2 \mathrm{~mm}$; tegangan sumber 5 Volt; resistor 125 megaOhm)

\begin{tabular}{|c|c|c|c|c|c|}
\hline $\begin{array}{c}V \\
\text { eksp }\end{array}$ & $T$ & $B$ & $\begin{array}{c}V \\
\text { teori }\end{array}$ & $\left(\mathrm{V}_{\text {te }}-\mathrm{V}_{\text {eksp }}\right)^{2}$ & $\left(\mathrm{~V}_{\text {avg }}-\mathrm{V}_{\text {eksp }}\right)^{2}$ \\
\hline 0 & 0 & 20.97 & 0.00 & 0.0000 & 18.3374 \\
\hline 1 & 0.02 & 20.97 & 1.71 & 0.5080 & 5.1630 \\
\hline 2.01 & 0.04 & 20.97 & 2.84 & 0.6869 & 2.6316 \\
\hline 2.66 & 0.06 & 20.97 & 3.58 & 0.8448 & 0.9452 \\
\hline 3.31 & 0.08 & 20.97 & 4.07 & 0.5713 & 0.2230 \\
\hline 3.81 & 0.1 & 20.97 & 4.39 & 0.3316 & 0.0052 \\
\hline 4.21 & 0.12 & 20.97 & 4.60 & 0.1492 & 0.0828 \\
\hline 4.57 & 0.14 & 20.97 & 4.73 & 0.0271 & 0.1745 \\
\hline 4.7 & 0.16 & 20.97 & 4.83 & 0.0157 & 0.2681 \\
\hline 4.8 & 0.18 & 20.97 & 4.89 & 0.0073 & 0.3455 \\
\hline 4.87 & 0.2 & 20.97 & 4.92 & 0.0030 & 0.3816 \\
\hline 4.9 & 0.22 & 20.97 & 4.95 & 0.0025 & 0.3941 \\
\hline 4.91 & 0.24 & 20.97 & 4.97 & 0.0033 & 0.4068 \\
\hline 4.92 & 0.26 & 20.97 & 4.98 & 0.0034 & 0.4459 \\
\hline 4.95 & 0.28 & 20.97 & 4.99 & 0.0013 & 0.5152 \\
\hline 5 & 0.3 & 20.97 & 4.99 & 0.0001 & 0.5152 \\
\hline
\end{tabular}




\begin{tabular}{|c|c|c|c|c|c|}
\hline $\begin{array}{c}V \\
\text { eksp }\end{array}$ & $T$ & $B$ & $\begin{array}{l}V \\
\text { teori }\end{array}$ & $\left(V_{\text {te }}-V_{\text {eksp }}\right)^{2}$ & $\left(V_{\text {avg }}-V_{\text {eksp }}\right)^{2}$ \\
\hline 5 & 0.32 & 20.97 & 4.99 & 0.0000 & 0.5152 \\
\hline 5 & 0.34 & 20.97 & 5.00 & 0.0000 & 0.5152 \\
\hline 5 & 0.36 & 20.97 & 5.00 & 0.0000 & 0.5152 \\
\hline 5 & 0.38 & 20.97 & 5.00 & 0.0000 & 0.5152 \\
\hline 5 & 0.4 & 20.97 & 5.00 & 0.0000 & 0.5152 \\
\hline 5 & 0.42 & 20.97 & 5.00 & 0.0000 & 0.5152 \\
\hline 5 & 0.44 & 20.97 & 5.00 & 0.0000 & 0.5152 \\
\hline 5 & 0.46 & 20.97 & 5.00 & 0.0000 & 0.5152 \\
\hline 5 & 0.48 & 20.97 & 5.00 & 0.0000 & 0.5152 \\
\hline 5 & 0.5 & 20.97 & 5.00 & 0.0000 & 0.5152 \\
\hline $\begin{array}{c}\bar{x} \\
4,282\end{array}$ & & & & $\begin{array}{l}\text { Jumlah } \\
3,1554\end{array}$ & $\begin{array}{l}\text { Jumlah } \\
36,1883\end{array}$ \\
\hline
\end{tabular}

Dapat dapat dilihatbahwa waktu proses pengisian kapasitor plat sejajar dengan jarak antar elektroda $1 \mathrm{~mm}$ lebih besar dibandingkan pada kondisi $2 \mathrm{~mm}$. Nilai tegangan secara eksperimen dan teori diplotkan kurva hubungan tegangan dan waktu pada Gambar 7.

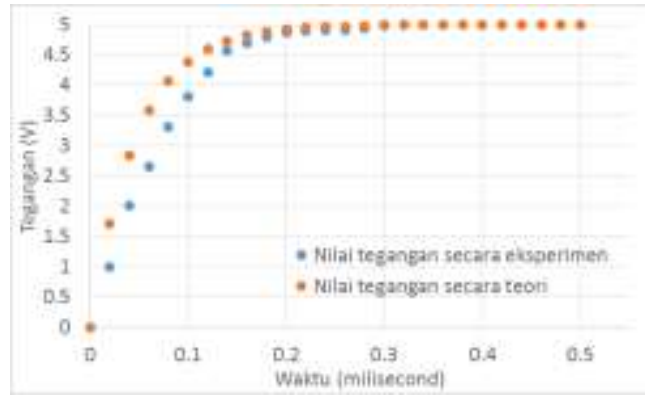

Gambar 7. Kurva perubahan tegangan $V_{c}(t)$ (kapasitor elektroda plat sejajar berdielektrik udara dengan jarak antar elektroda $2 \mathrm{~mm}$; tegangan sumber 5 Volt; resistor 125 megaOhm)

Pada pengujian ini diketahui nilai resistansi $R$ sebesar 125 megaOhm, jarak antar elektroda $d$ sebesar 0,002 meter, luasan elektroda $A$ sebesar 0,087 meter $^{2}$, dan nilai $\varepsilon_{0}$ sebesar $8,85 \times 10^{-12} \mathrm{~F} / \mathrm{m}$, serta nilai $b$ yang diperoleh dari fitting data sebesar 20,9693. Data hasil pengujian menunjukan hasil pengukuran kapasitansi sebesar 3,815 × 10-10 Farad dan konstanta dielektrik udara sebesar 0,991 . Kesesuaian antara teori dan hasil secara eksperimen didapatkan $R^{2}$ sebesar 0,9128 .

Tabel 4 menunjukan hasil akuisisi data nilai tegangan secara eksperimen dan teori untuk kapasitor elektroda plat sejajar berdielektrik udara pada proses pengisian dengan jarak antar elektroda $3 \mathrm{~mm}$, tegangan sumber 5 Volt, dan hambatansebesar 125 megaOhm.

Tabel 4. Data nilai perubahan tegangan tiap waktu pada pengisian kapasitor elektroda plat sejajar berdielektrik udara (dengan jarak antar elektroda $3 \mathrm{~mm}$; tegangan sumber 5 Volt; resistor 125 megaOhm)

\begin{tabular}{|c|c|c|c|c|c|}
\hline $\begin{array}{c}V \\
\text { eksp }\end{array}$ & $T$ & $B$ & $\begin{array}{c}V \\
\text { teori }\end{array}$ & $\left(V_{\text {te }}-V_{\text {eksp }}\right)^{2}$ & $\left(V_{\text {avg }}-V_{\text {eksp }}\right)^{2}$ \\
\hline 0 & 0 & 31.01 & 0.00 & 0.0000 & 19.8607 \\
\hline 1.5 & 0.02 & 31.01 & 2.31 & 0.6572 & 2.3610 \\
\hline 2.92 & 0.04 & 31.01 & 3.55 & 0.4013 & 0.8771 \\
\hline 3.52 & 0.06 & 31.01 & 4.22 & 0.4928 & 0.1271 \\
\hline 4.1 & 0.08 & 31.01 & 4.58 & 0.2319 & 0.0019 \\
\hline 4.5 & 0.1 & 31.01 & 4.77 & 0.0756 & 0.0642 \\
\hline 4.71 & 0.12 & 31.01 & 4.88 & 0.0285 & 0.1249 \\
\hline 4.81 & 0.14 & 31.01 & 4.93 & 0.0156 & 0.1967 \\
\hline 4.9 & 0.16 & 31.01 & 4.96 & 0.0042 & 0.2435 \\
\hline 4.95 & 0.18 & 31.01 & 4.98 & 0.0010 & 0.2740 \\
\hline 4.98 & 0.2 & 31.01 & 4.99 & 0.0001 & 0.2846 \\
\hline 4.99 & 0.22 & 31.01 & 4.99 & 0.0000 & 0.2846 \\
\hline 4.99 & 0.24 & 31.01 & 5.00 & 0.0000 & 0.2954 \\
\hline 5 & 0.26 & 31.01 & 5.00 & 0.0000 & 0.2954 \\
\hline 5 & 0.28 & 31.01 & 5.00 & 0.0000 & 0.2954 \\
\hline 5 & 0.3 & 31.01 & 5.00 & 0.0000 & 0.2954 \\
\hline 5 & 0.32 & 31.01 & 5.00 & 0.0000 & 0.2954 \\
\hline 5 & 0.34 & 31.01 & 5.00 & 0.0000 & 0.2954 \\
\hline 5 & 0.36 & 31.01 & 5.00 & 0.0000 & 0.2954 \\
\hline 5 & 0.38 & 31.01 & 5.00 & 0.0000 & 0.2954 \\
\hline 5 & 0.4 & 31.01 & 5.00 & 0.0000 & 0.2954 \\
\hline 5 & 0.42 & 31.01 & 5.00 & 0.0000 & 0.2954 \\
\hline 5 & 0.44 & 31.01 & 5.00 & 0.0000 & 0.2954 \\
\hline 5 & 0.46 & 31.01 & 5.00 & 0.0000 & 0.2954 \\
\hline 5 & 0.48 & 31.01 & 5.00 & 0.0000 & 0.2954 \\
\hline 5 & 0.5 & 31.01 & 5.00 & 0.0000 & 0.2954 \\
\hline $\begin{array}{c}\bar{x} \\
4,457\end{array}$ & & & & $\begin{array}{l}\text { Jumlah } \\
1,9081\end{array}$ & $\begin{array}{l}\text { Jumlah } \\
28,8352\end{array}$ \\
\hline
\end{tabular}

Perilaku pengisian kapasitor plat sejajar berdieletrik udara dengan jarak elektroda 3 $\mathrm{mm}$ memiliki waktu pengisian yang lebih singkat dibandingkan dengan kapasitor 
berjarak $2 \mathrm{~mm}$ dan $1 \mathrm{~mm}$. Hal tersebut menunjukan bahwa semakin besar jarak elektroda pada perangkat kapasitor plat sejajar akan menghasilkan kapasitansi yang semakin kecil.Nilai tegangan secara eksperimen dan teori diplotkan kurva hubungan tegangan dan waktu pada Gambar 8. Pada kondisi jarak antar elektroda sebesar $3 \mathrm{~mm}$, didapatkan nilai $b$ yang diperoleh dari fitting data sebesar 31,007. Data hasil pengujian menunjukan hasil pengukuran kapasitansi sebesar 2,58× 10-10 Farad dan konstanta dielektrik udara sebesar 1,0053. Kesesuaian antara teori dan hasil secara eksperimen didapatkan $\mathrm{R}^{2}$ sebesar 0,93383 . Nilai konstanta dielektrik udara yang telah didapatkan secara eksperimen melalui pengukuran kapasitansi metode charging berada pada kisaran 0,991 - 1,0053 dengan nilai $\mathrm{R}^{2}$ lebih besar dari 0,9.

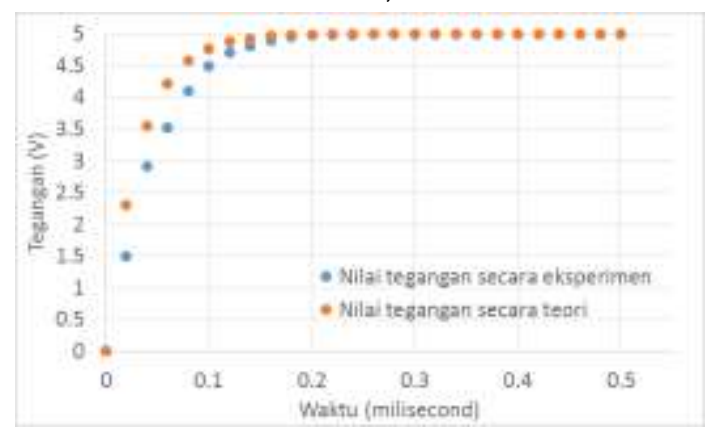

Gambar 8. Kurva perubahan tegangan $V_{c}(t)$ (kapasitor elektroda plat sejajar berdielektrik udara dengan jarak antar elektroda $3 \mathrm{~mm}$; tegangan sumber 5 Volt; resistor 125 megaOhm)

Pengukuran konstanta dielektrik udara pada kondisi pengosongan (discharging)

Pengujian kali ini yaitu pengosongan(discharging) pada elektroda plat sejajar (dengan jarak antar elektroda $1 \mathrm{~mm}$ ) dengan dielektrik udara. Pengosongan (discharging) dilakukan sesuai dengan skema rangkaian pada Gambar 5. Prosesini disebutsebagai proses pengosongan secara eksperimen yang menghasilkan tegangan eksperimen pada setiap 20 milisecond dari tegangan awal 5 volt hingga 0 volt yang kemudian akan dibandingkan dengan hasil prediksi teori. Tabel 5 menunjukan data tegangan eksperimen pada proses pengosongan elektroda kapasitor plat sejajar berdielektrik udara-(dengan jarak antar elektroda $1 \mathrm{~mm}$ dan hambatan sebesar 125 megaOhm).

Tabel 5. Data nilai perubahan tegangan tiap waktu pada pengosongan kapasitor elektroda plat sejajar berdielektrik udara (dengan jarak antar elektroda $1 \mathrm{~mm}$; resistor $125 \mathrm{megaOhm}$ )

\begin{tabular}{|c|c|c|c|c|c|}
\hline $\begin{array}{c}V \\
\text { eksp }\end{array}$ & $T$ & $B$ & $\begin{array}{c}V \\
\text { teori }\end{array}$ & $\left(V_{\text {te- }} \text { eksp }\right)^{2}$ & $\left(V_{\text {avg }} V_{\text {eksp }}\right)^{2}$ \\
\hline 5 & 0 & 10.29 & 5.00 & 0.0000 & 16.1882 \\
\hline 4.02 & 0.02 & 10.29 & 4.07 & 0.0025 & 9.2627 \\
\hline 3.23 & 0.04 & 10.29 & 3.31 & 0.0069 & 5.0781 \\
\hline 2.6 & 0.06 & 10.29 & 2.70 & 0.0093 & 2.6356 \\
\hline 2.09 & 0.08 & 10.29 & 2.19 & 0.0110 & 1.2398 \\
\hline 1.68 & 0.1 & 10.29 & 1.79 & 0.0114 & 0.4949 \\
\hline 1.35 & 0.12 & 10.29 & 1.45 & 0.0109 & 0.1395 \\
\hline 1.08 & 0.14 & 10.29 & 1.18 & 0.0108 & 0.0107 \\
\hline 0.87 & 0.16 & 10.29 & 0.96 & 0.0087 & 0.0114 \\
\hline 0.7 & 0.18 & 10.29 & 0.78 & 0.0071 & 0.0765 \\
\hline 0.56 & 0.2 & 10.29 & 0.64 & 0.0061 & 0.1735 \\
\hline 0.45 & 0.22 & 10.29 & 0.52 & 0.0048 & 0.2772 \\
\hline 0.36 & 0.24 & 10.29 & 0.42 & 0.0040 & 0.3801 \\
\hline 0.29 & 0.26 & 10.29 & 0.34 & 0.0029 & 0.4713 \\
\hline 0.24 & 0.28 & 10.29 & 0.28 & 0.0016 & 0.5425 \\
\hline 0.19 & 0.3 & 10.29 & 0.23 & 0.0015 & 0.6186 \\
\hline 0.15 & 0.32 & 10.29 & 0.19 & 0.0013 & 0.6832 \\
\hline 0.12 & 0.34 & 10.29 & 0.15 & 0.0010 & 0.7337 \\
\hline 0.1 & 0.36 & 10.29 & 0.12 & 0.0005 & 0.7683 \\
\hline 0.08 & 0.38 & 10.29 & 0.10 & 0.0004 & 0.8038 \\
\hline 0.06 & 0.4 & 10.29 & 0.08 & 0.0005 & 0.8400 \\
\hline 0.05 & 0.42 & 10.29 & 0.07 & 0.0003 & 0.8585 \\
\hline 0.04 & 0.44 & 10.29 & 0.05 & 0.0002 & 0.8771 \\
\hline 0.03 & 0.46 & 10.29 & 0.04 & 0.0002 & 0.8959 \\
\hline 0.03 & 0.48 & 10.29 & 0.04 & 0.0000 & 0.8959 \\
\hline 0.02 & 0.5 & 10.29 & 0.03 & 0.0001 & 0.9150 \\
\hline $\bar{x}$ & & & & $J u m l a h$ & Jumlah \\
\hline, 977 & & & & \\
\hline & & & & \\
\hline
\end{tabular}

Pada pengujian ini diketahui nilai resistansi $R$ sebesar 125 megaOhm, jarak antar elektroda $d$ sebesar 0,001 meter, luasan elektroda $A$ sebesar 0,087 meter $^{2}$, dan nilai $\varepsilon_{0}$ sebesar $8,85 \times 10^{-12} \mathrm{~F} / \mathrm{m}$. Telah didapatkan nilai $b$ dari fitting data sebesar 10,29122. Data hasil pengujian menunjukan hasil pengukuran 
Valentinus Galih Vidia Putra danAndrian Wijayono

kapasitansi sebesar 7,774 $\times 10^{-10}$ Farad dan konstanta dielektrik udara sebesar 1,0096. Kesesuaian antara teori dan hasil secara eksperimen didapatkan $\mathrm{R}^{2}$ sebesar 0,99773. Nilai tegangan secara eksperimen dan teori diplotkan kurva hubungan tegangan dan waktu pada Gambar 9.

Pada pengujian selanjutnya telah diamati pengaruh jarak antar elektroda pada proses pengosongan (discharging) perangkat kapasitor berdielektrik udara terhadap nilai kapasitansi dan konstanta dielektrik yang terukur. Masing-masing pengujian pengosongan dilakukan pada jarak antar elektroda sebesar $1 \mathrm{~mm}, 2 \mathrm{~mm}$ dan $3 \mathrm{~mm}$. Pada Tabel 6 di bawah ini adalah hasil akuisisi data nilai tegangan secara eksperimen dan teori untuk kapasitor elektroda plat sejajar berdielektrik udara pada proses pengosongan dengan jarak antar elektroda $2 \mathrm{~mm}$ dan hambatansebesar 125 megaOhm.

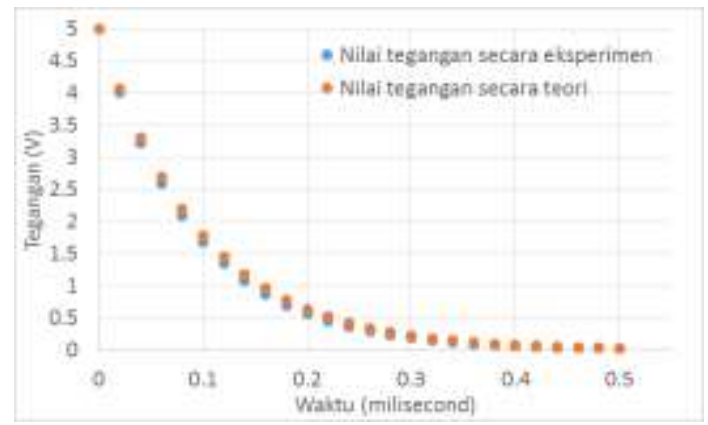

Gambar 9. Kurva perubahan

tegangan $V_{c}(t)$ (kapasitor elektroda plat sejajar berdielektrik udara dengan jarak antar elektroda $1 \mathrm{~mm}$ dan resistor 125 megaOhm)

Tabel 6. Data nilai perubahan tegangan tiap waktu pada pengosongan kapasitor elektroda plat sejajar berdielektrik udara (dengan jarak antar elektroda $2 \mathrm{~mm}$; resistor $125 \mathrm{megaOhm}$ )

\begin{tabular}{|c|c|c|c|c|c|}
\hline $\begin{array}{c}V \\
\text { eksp }\end{array}$ & $T$ & $B$ & $\begin{array}{c}V \\
\text { teori }\end{array}$ & $\left(\mathrm{V}_{\text {te }}-\mathrm{V}_{\text {eksp }}\right)^{2}$ & $\left(\mathrm{~V}_{\text {avg }}-\mathrm{V}_{\text {eksp }}\right)^{2}$ \\
\hline 5 & 0 & 20.08 & 5.00 & 0.0000 & 19.7136 \\
\hline 3.29 & 0.02 & 20.08 & 3.35 & 0.0031 & 2.5600 \\
\hline 2.16 & 0.04 & 20.08 & 2.24 & 0.0062 & 0.7396 \\
\hline 1.42 & 0.06 & 20.08 & 1.50 & 0.0061 & 0.1369 \\
\hline 0.93 & 0.08 & 20.08 & 1.00 & 0.0053 & 0.0025 \\
\hline 0.61 & 0.1 & 20.08 & 0.67 & 0.0037 & 0.0256 \\
\hline 0.4 & 0.12 & 20.08 & 0.45 & 0.0024 & 0.0900 \\
\hline
\end{tabular}

\begin{tabular}{|c|c|c|c|c|c|}
\hline 0.26 & 0.14 & 20.08 & 0.30 & 0.0016 & 0.1521 \\
\hline 0.17 & 0.16 & 20.08 & 0.20 & 0.0010 & 0.2025 \\
\hline $\begin{array}{c}V \\
\text { eksp }\end{array}$ & $T$ & $B$ & $\begin{array}{c}V \\
\text { teori }\end{array}$ & $\left(\mathrm{V}_{\mathrm{te}}-\mathrm{V}_{\text {eksp }}\right)^{2}$ & $\left(V_{\text {avg }}-V_{\text {eksp }}\right)^{2}$ \\
\hline 0.11 & 0.18 & 20.08 & 0.13 & 0.0006 & 0.2304 \\
\hline 0.08 & 0.2 & 20.08 & 0.09 & 0.0001 & 0.2601 \\
\hline 0.05 & 0.22 & 20.08 & 0.06 & 0.0001 & 0.2809 \\
\hline 0.03 & 0.24 & 20.08 & 0.04 & 0.0001 & 0.2916 \\
\hline 0.02 & 0.26 & 20.08 & 0.03 & 0.0000 & 0.3025 \\
\hline 0.01 & 0.28 & 20.08 & 0.02 & 0.0001 & 0.3025 \\
\hline 0.01 & 0.3 & 20.08 & 0.01 & 0.0000 & 0.3025 \\
\hline 0.01 & 0.32 & 20.08 & 0.01 & 0.0000 & 0.3136 \\
\hline 0 & 0.34 & 20.08 & 0.01 & 0.0000 & 0.3136 \\
\hline 0 & 0.36 & 20.08 & 0.00 & 0.0000 & 0.3136 \\
\hline 0 & 0.38 & 20.08 & 0.00 & 0.0000 & 0.3136 \\
\hline 0 & 0.4 & 20.08 & 0.00 & 0.0000 & 0.3136 \\
\hline 0 & 0.42 & 20.08 & 0.00 & 0.0000 & 0.3136 \\
\hline 0 & 0.44 & 20.08 & 0.00 & 0.0000 & 0.3136 \\
\hline 0 & 0.46 & 20.08 & 0.00 & 0.0000 & 0.3136 \\
\hline 0 & 0.48 & 20.08 & 0.00 & 0.0000 & 0.3136 \\
\hline 0 & 0.5 & 20.08 & 0.00 & 0.0000 & 0.3136 \\
\hline $\begin{array}{c}\bar{x} \\
0,56\end{array}$ & & & & $\begin{array}{l}\text { Jumlah } \\
0,0306\end{array}$ & $\begin{array}{c}\text { Jumlah } \\
28,7293\end{array}$ \\
\hline
\end{tabular}

Pada pengujian ini diketahui nilai resistansi $R$ sebesar 125 megaOhm, jarak antar elektroda $d$ sebesar 0,002 meter, luasan elektroda $A$ sebesar 0,087 meter $^{2}$, dan nilai $\varepsilon_{0}$ sebesar $8,85 \times 10^{-12} \mathrm{~F} / \mathrm{m}$. Telah didapatkan nilai $b$ dari fitting data sebesar 20.0846. Data hasil pengujian menunjukan hasil pengukuran

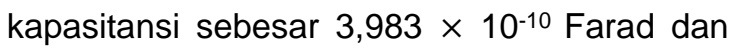
konstanta dielektrik udara sebesar 1,03465. Kesesuaian antara teori dan hasil secara eksperimen didapatkan $\mathrm{R}^{2}$ sebesar 0.9989 . Nilai tegangan secara eksperimen dan teori diplotkan kurva hubungan tegangan dan waktu pada Gambar 10.

Tabel 7 menunjukan data tegangan eksperimen pada proses pengosongan elektroda kapasitor plat sejajar berdielektrik udara.(dengan jarak antar elektroda $3 \mathrm{~mm}$ dan hambatan sebesar 125 megaOhm). Pada pengujian ini diketahui nilai resistansi $R$ sebesar 125 megaOhm, jarak antar elektroda $d$ sebesar 0,003 meter, luasan elektroda $A$ sebesar 0,087 meter $^{2}$, dan nilai $\varepsilon_{0}$ sebesar 
$8,85 \times 10^{-12} \mathrm{~F} / \mathrm{m}$. Telah didapatkan nilai $b$ dari fitting data sebesar 31.03535. Data hasil pengujian menunjukan hasil pengukuran kapasitansi sebesar 2,578 $\times 10^{-10}$ Farad dan konstanta dielektrik udara sebesar 1.0044 . Kesesuaian antara teori dan hasil secara eksperimen didapatkan $\mathrm{R}^{2}$ sebesar 0.9734 . Nilai tegangan secara eksperimen dan teori diplotkan kurva hubungan tegangan dan waktu pada Gambar 11.

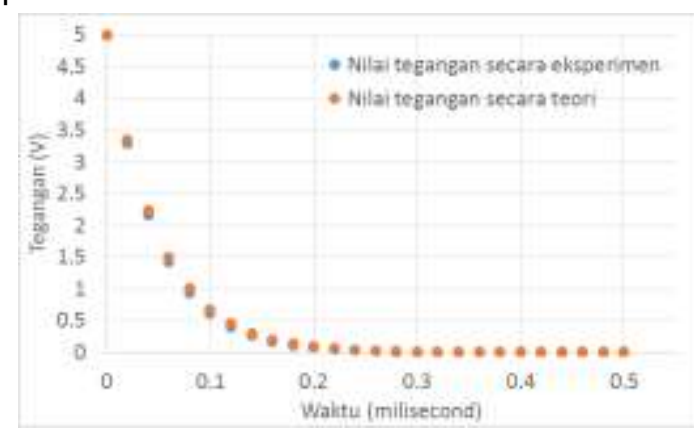

Gambar 10. Kurva perubahan tegangan $V_{c}(t)$ (kapasitor elektroda plat sejajar berdielektrik udara dengan jarak antar elektroda $2 \mathrm{~mm}$ dan resistor 125 megaOhm)

Tabel 7. Data nilai perubahan tegangan tiap waktu pada pengosongan kapasitor elektroda plat sejajar berdielektrik udara (dengan jarak antar elektroda $3 \mathrm{~mm}$; resistor $125 \mathrm{megaOhm}$ )

\begin{tabular}{|c|c|c|c|c|c|}
\hline $\begin{array}{c}V \\
\text { eksp }\end{array}$ & $T$ & $B$ & $\begin{array}{c}V \\
\text { teori }\end{array}$ & $\left(V_{\text {te }}-V_{\text {eksp }}\right)^{2}$ & $\left(V_{\text {avg }} V_{\text {eksp }}\right)^{2}$ \\
\hline 5 & 0 & 31.04 & 5.00 & 0.0000 & 21.4797 \\
\hline 2 & 0.02 & 31.04 & 2.69 & 0.4731 & 0.5694 \\
\hline 1.12 & 0.04 & 31.04 & 1.44 & 0.1055 & 0.0239 \\
\hline 0.52 & 0.06 & 31.04 & 0.78 & 0.0659 & 0.0031 \\
\hline 0.31 & 0.08 & 31.04 & 0.42 & 0.0116 & 0.0133 \\
\hline 0.25 & 0.1 & 31.04 & 0.22 & 0.0007 & 0.0508 \\
\hline 0.14 & 0.12 & 31.04 & 0.12 & 0.0004 & 0.0873 \\
\hline 0.07 & 0.14 & 31.04 & 0.06 & 0.0000 & 0.1059 \\
\hline 0.04 & 0.16 & 31.04 & 0.03 & 0.0000 & 0.1193 \\
\hline 0.02 & 0.18 & 31.04 & 0.02 & 0.0000 & 0.1263 \\
\hline 0.01 & 0.2 & 31.04 & 0.01 & 0.0000 & 0.1193 \\
\hline 0.02 & 0.22 & 31.04 & 0.01 & 0.0002 & 0.1335 \\
\hline 0 & 0.24 & 31.04 & 0.00 & 0.0000 & 0.1335 \\
\hline 0 & 0.26 & 31.04 & 0.00 & 0.0000 & 0.1335 \\
\hline 0 & 0.28 & 31.04 & 0.00 & 0.0000 & 0.1335 \\
\hline 0 & 0.3 & 31.04 & 0.00 & 0.0000 & 0.1335 \\
\hline 0 & 0.32 & 31.04 & 0.00 & 0.0000 & 0.1335 \\
\hline
\end{tabular}

\begin{tabular}{|c|c|c|c|c|c|}
\hline $\begin{array}{c}V \\
\text { eksp }\end{array}$ & $T$ & $B$ & $\begin{array}{c}V \\
\text { teori }\end{array}$ & $\left(\mathrm{V}_{\text {te- }}-\mathrm{V}_{\text {eksp }}\right)^{2}$ & $\left(\mathrm{~V}_{\text {avg }}-\mathrm{V}_{\text {eksp }}\right)^{2}$ \\
\hline 0 & 0.34 & 31.04 & 0.00 & 0.0000 & 0.1335 \\
\hline 0 & 0.36 & 31.04 & 0.00 & 0.0000 & 0.1335 \\
\hline 0 & 0.38 & 31.04 & 0.00 & 0.0000 & 0.1335 \\
\hline 0 & 0.4 & 31.04 & 0.00 & 0.0000 & 0.1335 \\
\hline 0 & 0.42 & 31.04 & 0.00 & 0.0000 & 0.1335 \\
\hline 0 & 0.44 & 31.04 & 0.00 & 0.0000 & 0.1335 \\
\hline 0 & 0.46 & 31.04 & 0.00 & 0.0000 & 0.1335 \\
\hline 0 & 0.48 & 31.04 & 0.00 & 0.0000 & 0.1335 \\
\hline 0 & 0.5 & 31.04 & 0.00 & 0.0000 & 0.1335 \\
\hline $\bar{x}$ & & & $\begin{array}{c}\text { Jumlah } \\
0,0306\end{array}$ & $\begin{array}{c}\text { Jumlah } \\
28,7293\end{array}$ \\
\hline 0,56 & \multicolumn{5}{|l}{} \\
\hline
\end{tabular}

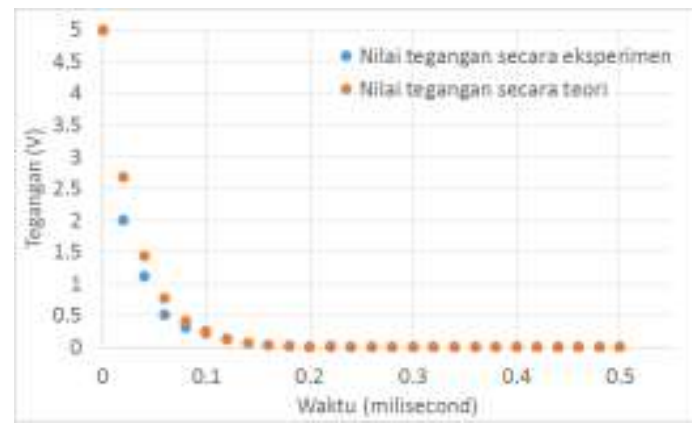

Gambar 11. Kurva perubahan tegangan $V_{c}(t)$ (kapasitor elektroda plat sejajar berdielektrik udara dengan jarak antar elektroda $3 \mathrm{~mm}$ dan resistor 125 megaOhm)

Perilaku pengosongan kapasitor plat sejajar berdieletrik udara dengan jarak elektroda $3 \mathrm{~mm}$ memiliki waktu pengosongan yang lebih singkat dibandingkan dengan kapasitor berjarak $2 \mathrm{~mm}$ dan $1 \mathrm{~mm}$. Hal tersebut menunjukan bahwa semakin besar jarak elektroda pada perangkat kapasitor plat sejajar akan menghasilkan kapasitansi yang semakin kecil. Nilai konstanta dielektrik udara yang telah didapatkan secara eksperimen melalui pengukuran kapasitansi metode discharging berada pada kisaran 1,0044 1,0347 dengan nilai $R^{2}$ lebih besar dari 0,9.

\section{PEMBAHASAN}

Pengukuran konstanta dielektrik udara telah dilakukan pada penelitian ini dengan menggunakan perangkat elektroda plat sejajar berbasis mikrokontroller Arduino Uno. Pengamatan telah dilakukan untuk variasi jarak antar plat elektroda masing-masing 1 $\mathrm{mm}, 2 \mathrm{~mm}$ dan $3 \mathrm{~mm}$. Hasil pengukuran 
konstanta dielektrik udara dan nilai kapasitansi telah diukur untuk setiap variasi kondisi jarak antar elektroda.

Hasil pengamatan menunjukan bahwa jarak antar elektroda mempengaruhi laju pengisian (charging) dan pengosongan (discharging) perangkat kapasitor elektroda plat sejajar. Tabel 8 dan Gambar 12 menunjukan bahwa semakin besar jarak antar elektroda akan menghasilkan waktu proses pengisian dan pengosongan yang lebih singkat. Laju pengisian dan pengosongan perangkat kapasitor secara langsung menggambarkan besarnya nilai kapasitansi dari suatu perangkat kapasitor (Putra dkk, 2019). Berdasarkan hal tersebut, semakin besar jarak antar elektroda akan menghasilkan nilai kapasitansi yang lebih kecil. Tabel 9 menunjukan besar nilai kapasitansi perangkat kapasitor elektroda plat sejajar pada kondisi jarak antar elektroda masing-masing $1 \mathrm{~mm}, 2$ $\mathrm{mm}$ dan $3 \mathrm{~mm}$. Gambar 12(a) dan Gambar 12(b) menunjukan perbandingan laju perubahan tegangan $V_{c}(t)$ perangkat kapasitor elektroda plat sejajar untuk masing-masing kondisi jarak antar elektroda saat proses charging dan discharging.

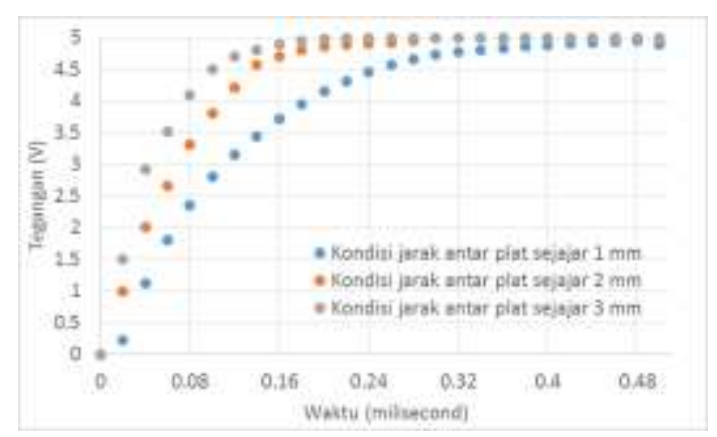

(a)

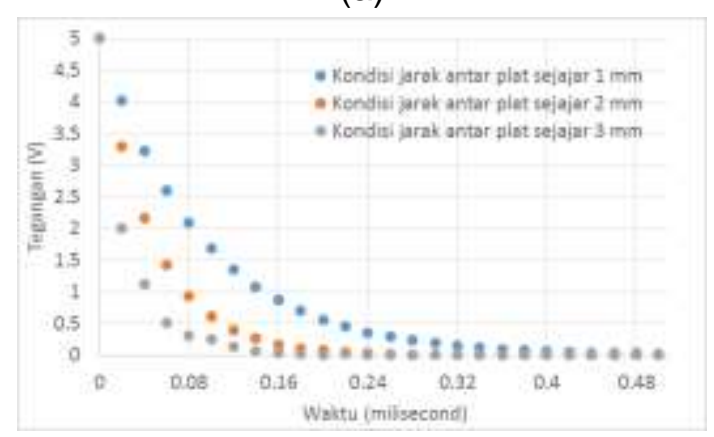

(b)

Gambar 12. Laju perubahan tegangan $V_{c}$ terhadap waktu tperangkat kapasitor pada proses (a) charging dan (b) discharging

Tabel 8. Waktu yang dibutuhkan pada proses pengisian dan pengosongan perangkat kapasitor elektroda plat sejajar untuk mencapai keadaan steady state

\begin{tabular}{ccc}
\hline \multirow{2}{*}{$\begin{array}{c}\text { Kondisi jarak } \\
\text { antar } \\
\text { elektroda }\end{array}$} & \multicolumn{2}{c}{$\begin{array}{c}\text { Waktu yang dibutuhkan untuk } \\
\text { mencapai keadaan steady state }\end{array}$} \\
\cline { 2 - 3 } & $\begin{array}{c}\text { Metode } \\
\text { pengisian } \\
\text { (charging) }\end{array}$ & $\begin{array}{c}\text { Metode } \\
\text { pengosongan } \\
\text { (discharging) }\end{array}$ \\
\hline $1 \mathrm{~mm}$ & 500 milisecond & 500 milisecond \\
$2 \mathrm{~mm}$ & 280 milisecond & 300 milisecond \\
$3 \mathrm{~mm}$ & 240 milisecond & 220 milisecond \\
\hline
\end{tabular}

Tabel 9. Nilai kapasitansi $(C)$ perangkat kapasitor elektroda plat sejajar untuk mencapai keadaan steady state

\begin{tabular}{ccc}
\hline \multirow{2}{*}{\begin{tabular}{c} 
Kondisi jarak $\begin{array}{c}\text { antar } \\
\text { elektroda }\end{array}$ \\
\cline { 2 - 3 }
\end{tabular}} & $\begin{array}{c}\text { Nilai kapasitansi perangkat } \\
\text { kapasitor elektroda plat sejajar }\end{array}$ \\
\cline { 2 - 3 } $\begin{array}{c}\text { Metode } \\
\text { pengisian } \\
\text { (charging) }\end{array}$ & $\begin{array}{c}\text { Metode } \\
\text { pengosongan } \\
\text { (discharging) }\end{array}$ \\
\hline $1 \mathrm{~mm}$ & $7,765 \times 10^{-10} \mathrm{~F}$ & $7,774 \times 10^{-10} \mathrm{~F}$ \\
$2 \mathrm{~mm}$ & $3,815 \times 10^{-10} \mathrm{~F}$ & $3,983 \times 10^{-10} \mathrm{~F}$ \\
$3 \mathrm{~mm}$ & $2,58 \times 10^{-10} \mathrm{~F}$ & $2,578 \times 10^{-10} \mathrm{~F}$ \\
\hline
\end{tabular}

Hasil yang didapatkan pada Tabel 8 dan Tabel 9 sesuai dengan persamaan (1) mengenai hubungan kapasitansi dan jarak antar elektroda konduktif yang terpisah oleh dielektrik, yaitu semakin besar jarak antar elektroda maka semakin kecil kapasitansi yang diperoleh. Telah didpatkan nilai kapasitansi pada proses pengisian dan pengosongan yang relatif sama untuk kondisi jarak antar elektroda yang sama. Hal tersebut sesuai dengan persamaan (5) dan (6), bahwa waktu pengisian dan pengosongan dari satu perangkat kapasitorakan memiliki nilai yang sama.

Pada penelitian ini telah dilakukan pengamatan pengaruh kondisi jarak antar elektroda plat sejajar terhadap hasil pengukuran konstanta dielektrik udara. Gambar 13 menunjukan perbandingan nilai konstanta dielektrik udara pada kondisi jarak antar elektroda plat sejajar masing-masing 1 $\mathrm{mm}, 2 \mathrm{~mm}$ dan $3 \mathrm{~mm}$. Pada masing-masing 
kondisi jarak antar elektroda plat sejajar menunjukan nilai konstanta dielektrik $\left(\varepsilon_{r}\right)$ udara yang relatif sama, yaitu pada kisaran 0,991 - 1.0346dengan nilai kesesuaian $R^{2}$ masing-masing lebih besar dari 0,9.Grafik pada Gambar 13 menunjukan bahwa kondisi jarak antar elektroda plat sejajar tidak mempengaruhi hasil pengukuran nilai konstanta dielektrik udara. Perubahan pada kondisi jarak antar plat elektroda terbukti berpengaruh terhadap nilai kapasitansi, namun tidak berpengaruh secara signifikan terhadap hasil pengukuran nilai konstanta dielektrik udara, sesuai dengan data yang diperoleh pada Tabel 9 dan Gambar 13.

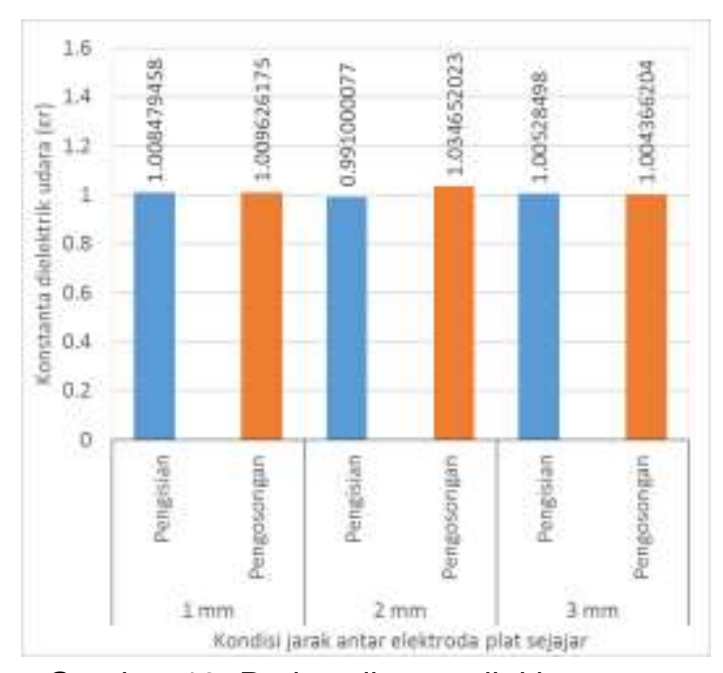

Gambar 13. Perbandingan nilai konstanta dielektrik udara $\left(\varepsilon_{r}\right)$ pada kondisi jarak antar elektroda plat sejajar masing-masing $1 \mathrm{~mm}, 2$ $\mathrm{mm}$ dan $3 \mathrm{~mm}$

\section{PENUTUP}

Pada penelitian ini telah ditemukan sebuah prototipe alat pengukur konstanta dielektrik udara dan nilai kapasitansi menggunakan perangkat mikrokontroler Arduino Uno. Pengaruh jarak antar elektroda plat sejajar terhadap nilai kapasitansi telah diamati pada penelitian ini. Semakin besar jarak antar elektroda plat sejajar maka semakin kecil kapasitansi yang diperoleh. Telah didapatkan bahwa perbedaan kondisi jarak antar elektroda dapat menghasilkan nilai pengukuran konstanta dielektrik yang relatif sama.Hasil penelitian menunjukan bahwa perilaku pengisian dan pengosongan perangkat kapasitor plat-sejajar memiliki nilai $\mathrm{R}$ square $>0,9$, yang menunjukan korelasi cukup baik antara hasil prediksi dan eksperimen pada pengukuran kapasitansi. Hasil pengukuran menunjukan nilai konstanta dielektrik udara telah diukur dengan nilai sebesar 0,991-1.0346.

\section{UCAPAN TERIMAKASIH}

Ucapan terima kasih ditujukan kepadaLab. Fisika-Mekatronika Politeknik STTTBandung, serta rekan-rekan dosen PoliteknikSTTT Bandung yang telah memberikandukungan pada penelitian ini.

\section{REFERENCES}

Allagui, A., Elwakil, A. S., Fouda, M. E., \& Radwan, A. G. (2018). Capacitive behavior and stored energy in supercapacitors at power line frequencies. Journal of Power Sources, 390,142-147.

https://doi.org/10.1016/j.jpowsour.2018 .04 .035

Argin, M., \& Karady, G. G. (2008). Characterization of polyurethane foam dielectric strength. IEEE Transactions on Dielectrics and Electrical Insulation, 15(2), 350-356. https://doi.org/10.1109/TDEl.2008.4483452

Arshad, A., Khan, S., Alam, A. H. M. Z., Tasnim, R., Gunawan, T. S., Ahmad, R., \& Nataraj, C. (2016). An activity monitoring system for senior citizens living independently using capacitive sensing technique. In IEEE International Instrumentation and Measurement Technology Conference Proceedings.

https://doi.org/10.1109/I2MTC.2016.75 20405

Arum, Z. H., Widodo, C. S., \& Saroja, G. (2015). Studi pengukuran nilai konstanta dielektrik oli berbagai viskositas pada frekuensi 100 $\mathrm{Hz}-2000 \mathrm{~Hz}$. Skripsi. Malang: Universitas Brawijaya.

Bandyopadhyay, P. C., Chaki, T. K., Srivastava, S., \& Sanyal, G. S. (1980). Dielectric behavior of polystyrene foam at microwave frequency. Polymer Engineering \& Science, 20(6), 441-446. 
https://doi.org/10.1002/pen.760200610

Cahyono, B.E., Supriyadi, S. \& Rofiq, M.A. (2017). Karakteristik Sensor Kapasitif Pelat Sejajar Dalam Aplikasinya Sebagai Instrumen Pengukur Curah Hujan Berbasis Arduino Uno. Indonesian Journal of Applied Physics. Vol. $7, \quad$ No. 2. https://doi.org/10.13057/ijap.v7i2.14248

Cheng, J., Amft, O., Bahle, G., \& Lukowicz, P. (2013). Designing Sensitive Wearable Capacitive Sensors for Activity Recognition. IEEE Sensors Journal, 13(10), 3935-3947. https://doi.org/10.1109/JSEN.2013.225 9693

Coyle, S., King-Tong Lau, Moyna, N., O'Gorman, D., Diamond, D., Di Francesco, F., Costanzo, D., Salvo, P., Trivella, M.G., De Rossi, D.E., Taccini, N., Paradiso, R., Porchet, J.A., Ridolfi, A., Luprano, J., Chuzel, C., Lanier, T., Cavalier, R., Schoumacker, S., Mourier, V., Chartier, I., Convert, R., De Moncuit, H., \& Bini, C. (2010). BIOTEX-Biosensing Textiles for Personalised Healthcare Management. IEEE Transactions on Information Technology in Biomedicine, 14(2), 364-370. https:/doi.org/10.1109/TITB.2009.203.8484

Dean, R. N., \& Rane, A. K. (2013). A Digital Frequency-Locked Loop System for Capacitance Measurement. IEEE Transactions on Instrumentation and Measurement, 62(4), 777-784. https://doi.org/10.1109/TIM.2013.2240 092

Halliday, D., Resnick, R., Walker. (1997). Fundamentals of Physics-Extended, 5th, John Wiley \& Sons, New York.

Hidayat, M. R., Widodo, C. S., \& Saroja, G. (2013). Kajian Karakteristik Biolistrik Kulit Ikan Lele (Clarias Batrachus) Dengan Metode Dielektrik Frekuensi Rendah. Dessertasi Doktor:Universitas Brawijaya.

Hoffmann, T., Eilebrecht, B., \& Leonhardt, S. (2011). Respiratory Monitoring System on the Basis of Capacitive Textile Force Sensors. IEEE Sensors Journal, 11(5), 1112-1119.

https://doi.org/10.1109/JSEN.2010.208 2524
Juansah, J., \& Irmansyah, I. (2012). Kajian Sifat Dielektrik Buah Semangka Dengan Pemanfaat Sinyal Listrik Frekuensi Rendah. Jurnal Sains MIPA Universitas Lampung, 5(3).

Karady, G. G., Argin, M., Rahmatian, F., \& Rose, A. H. (2004, October). Polyurethane foam application for high voltage insulation. In The 17th Annual Meeting of the IEEE Lasers and Electro-Optics Society, 2004. LEOS 2004. (pp. 526-529). IEEE. https://doi.org/10.1109/CEIDP.2004.136430 3

Karady, G. G., Argin, M., Shi, B., Rahmatian, F., \& Rose, A. H. (2003, September). Electrical properties of rigid pour polyurethane foam applied for high voltage insulation. In 2003 IEEE PES Transmission and Distribution Conference and Exposition (IEEE Cat. No. 03CH37495) (Vol. 3, pp. 870-874). IEEE. https://doi.org/10.1109/TDC.2003.1335051

Knott, E. F. (1993). Dielectric constant of plastic foams. IEEE transactions on antennas and propagation, 41(8), 1167-1171. https://doi.org/10.1109/8.244664

Kondalkar, V. V., Ryu, G., Lee, Y., \& Lee, K. (2019). Development of highly sensitive and stable humidity sensor for real-time monitoring of dissolved moisture in transformer-insulating oil. Sensors and Actuators B: Chemical, 286, 377-385. https://doi.org/10.1016/j.snb.2019.01.1 62

Laflamme, S., Saleem, H. S., Vasan, B. K., Geiger, R. L., Chen, D., Kessler, M. R., \& Rajan, K. (2013). Soft Elastomeric Capacitor Network for Strain Sensing Over Large Surfaces. IEEE/ASME Transactions on Mechatronics, 18(6), 1647-1654.

https://doi.org/10.1109/TMECH.2013.2 283365

Laflamme, S., Ubertini, F., Saleem, H., D'Alessandro, A., Downey, A., Ceylan, H., \& Materazzi, A. L. (2015). Dynamic Characterization of a Soft Elastomeric Capacitor for Structural Health Monitoring. Journal of Structural Engineering, 141(8), 04014186. https://ascelibrary.org/doi/abs/10.1061/ (ASCE)ST.1943-541X.0001151 
Lee, H. J., Hwang, S. H., Yoon, H. N., Lee, W. K., \& Park, K. S. (2015). Heart Rate Variability Monitoring during Sleep Based on Capacitively Coupled Textile Electrodes on a Bed. Sensors, 15(5), 11295-11311.

https://doi.org/10.3390/s150511295

Min, S.D., Yun, Y., \& Shin, H. (2014). Simplified Structural Textile Respiration Sensor Based on Capacitive Pressure Sensing Method. IEEE Sensors Journal, 14(9), 3245-3251.

https://doi.org/10.1109/JSEN.2014.232 7991

Mukhopadhyay, S. C. (2015). Wearable Sensors for Human Activity Monitoring: A Review. IEEE Sensors Journal, 15(3), 1321-1330. https://doi.org/10.1109/JSEN.2014.237 0945

Pereira, R. G., Naik, D. A., Naik, S. S., Naik, S. D., \& Cardoso, S. (2016). Capacitive sensor interfaced with arduino. International Journal of Science Technology \& Engineering, 2(15), 90-95.

Prihatnolo, S. T., Syakur, A., \& Facta, M. (2011). Pengukuran Tegangan Tembus Dielektrik Udara Pada berbagai Sela Dan Bentuk Elektroda Dengan Variasi Temperatur Sekitar. Dessertasi Doktor: Universitas Diponegoro.

Putra, V.G.V.,\& Purnomosari, E. (2016). Pengantar Listrik Magnet Dan Terapannya. CV. Mulia Jaya. ISBN 978-6020-72713-2-6.

Putra, V. G. V., Wijayono, A., Purnomosari, E., Ngadiono, N., \& Irwan, I. (2019). Metode Pengukuran Kapasitansi Dengan Menggunakan Mikrokontroler Arduino Uno. JIPFRI (Jurnal Inovasi Pendidikan Fisika Dan Riset IImiah), 3(1), 36-45. https://doi.org/10.30599/jipfri.v3i1.425

Rizza, H., Sudarti, S., \& Handono, S. (2019). Aplikasi Kapasitansi Meter Disertai Sistem Data Logger Berbasis Arduino Uno Untuk Uji Tingkat Kematangan Buah Pisang. FKIP e-PROCEEDING, 3(2), 1-5.

Rosita, F. N., \& Widodo, C. S. (2014). Kajian Pengaruh Campuran Lemak Babi Terhadap Konstanta Dielektrik Lemak Ayam Menggunakan Metode Dielektrik.Dessertasi
Doktor:Universitas Brawijaya.

Salvo, P., Di Francesco, F., Costanzo, D., Ferrari, C., Trivella, M. G., \& De Rossi, D. (2010). A Wearable Sensor for Measuring Sweat Rate. IEEE Sensors Journal, 10(10), 1557-1558. https://doi.org/10.1109/JSEN.2010.204 6634

Tang, X., Li, S., Shen, L., Zhao, W., Yang, X., Williams, R., Liu, J., Tan, Z., Hall, N. \& $\begin{array}{llll}\text { Sun, } & \text { N. } & \text { (2019). } & 18.2\end{array}$ 16fJ/Conversion-Step Time-Domain Two-Step Capacitance-to-Digital Converter. In 2019 IEEE International Solid- State Circuits Conference (ISSCC).

https://doi.org/10.1109/ISSCC.2019.86 62359

Xia, J., Chen, F., Li, J., \& Tao, N. (2009). Measurement of the quantum capacitance of graphene. Nature Nanotechnology, 4(8), 505-509. https://doi.org/10.1038/nnano.2009.17 7 